\title{
Can a Rights-based Approach Help in Achieving the Millennium Development Goals?
}

\section{Salil Shetty}

\section{Introduction}

A great deal of attention has recently been focused on the Millennium Development Goals (MDGs) and the broad-based international agreement supporting the MDGs means that they provide an important opportunity to promote a development agenda globally. What, then, is the relationship between a rights-based approach and the framing and implementation of the MDGs? And, more broadly does a rights-based approach help in achieving development or human development? This article argues that although more discussion on this question is needed, a rights-based approach does contribute positively to human development and the fulfilment of the MDGs. The first section will focus on how a rights-based approach underlies and frames the MDGs. The next section will examine how a rights-based approach to implementing the MDGs strengthens their effects.

\section{What are the MDGs?}

The MDGs derive from the Millennium Declaration of September 2000, which spells out the following values: Freedom, Equality, Solidarity, Tolerance, Respect for Nature and Shared Responsibility. And they are a clarion call of 189 governments, on behalf of their citizens, to 'free our fellow men, women and children from the abject and dehumanising conditions of extreme poverty, to which more than a billion of them are currently subjected. We are committed to making the right to development a reality for everyone and to freeing the entire human race from want' (emphasis added). The UN Secretary General's road map towards the implementation of the UN Millennium Declaration goes even further, in saying that human rights should be at the centre of peace, security and development programmes.
From that point of view, MDGs are fundamentally located within a human rights framework, with a clear connection to the discourse on the right to development. Rights are the normative basis for the MDGs. By linking the MDGs in a very direct way to the right to development, which was reaffirmed at the World Conference on Human Rights in 1993 by the community of nations in the UN as a whole, there is no room for understanding the MDGs outside of rights-based perspective. A rights-based framework ensures that the MDGs, which are outcomes, are achieved through a process that respects the values, standards and principles outlined in the Universal Declaration of Human Rights (UDHR).

But more importantly, the MDGs are unique because for the first time:

1. They represent a compact between the so-called developed and developing countries, the Bretton Woods Institutions (BWIs) and the World Trade Organisation (WTO), towards a shared responsibility.

2. They recognise that the goals are interlinked and achievable, but only if there is the necessary political will and the willingness to be accountable for actions.

3. They offer a minimum threshold-level of transparent and measurable outcomes, targets and indicators, rendering themselves open to independent monitoring.

The implementation unit is the nation-state, with the necessary support from international actors. As the minimum outcomes are already agreed in the form of the MDGs, the debate then shifts from what we are trying to achieve to whether or not it should be done. The debate is now much more on 
what the MDGs mean for each country. Moving to consider the implementation of the MDGs raises a series of questions: How can particular countries help achieve these goals? What does this entail? Should the goals be set higher? Over what time frame? Who is responsible? How do we hold the duty-bearers to account? As the goals are nationally adapted, heterodox development models and policies are generated to achieve the goals, owned and driven by the people of the country in an open and participatory manner, as active citizens. The MDGs require guaranteeing access to basic human needs and rights or guaranteeing conditions that enable access to these needs and rights.

The concepts of shared responsibility, indivisibility, non-discrimination, equality and accountability are part of the human rights discourse. And without these underlying rightsbased concepts, the MDGs lose their grip and become another set of lofty statements of intent. The MDGs derive their power from the legitimacy and value-base of human rights, particularly through the operationalisation of the right to development.

The human rights underpinning of the MDGs highlight how poverty is multidimensional and that development is about freedom in a very holistic sense: from misery and suffering, from hunger, from illiteracy, from disease, from poor housing and insecurity, etc. The absence of respect, dignity and choice is fundamentally what constitutes poverty. The rights-based framework of the MDGs emphasises how development is not a question of welfare or charity, but an issue of rights and entitlements, based on a recognition of the structural and underlying causes of poverty. As even the World Bank increasingly recognises: lack of voice, security, information and opportunity are not different from the denial of basic human rights. Certainly, injustice and discrimination of one kind or another are increasingly seen as key determinants of poverty and it is no coincidence that the very same determinants account for most human rights abuses.

For no other group of people does the existence and fair application of rule of law and human rights matter more than for poor and marginalised people. And it is the same people for whom the achievement of MDGs matter the most. It is the poor, particularly women, who have to live on land without legal titles, and who face constant violence: many places, from the favelas of São Paulo to the recent events in Darfur give weight to this point. Without a rights- based framework, achieving and sustaining the MDGs would not be possible.

\section{What do we mean by a rights- based framework and how can they help achieve MDGs?}

How are rights defined in terms of the MDGs? Legal understandings of rights stem from the international human rights discourse and are debated by specialists in international and national law. But in practice, claiming and establishing rights is a political process, mediated by the practice of power. It is the result of the interplay of intense contestation and struggle by myriad social actors, autonomous movements and in today's information society the media as well (see Nyamu-Musembi, page 31 this issue). And the right to full participation becomes the right which is necessary in order to claim all other rights - and achieve the MDGs (see Miller et al., page 31 this issue) whether at the local, national or international level, or in the realm of individuals or nation-states. In short, rights must be seen as more than legal rights.

The next section will consider how a rightsbased framework can help achieve the MDGs in particular contexts ${ }^{2}$ in two examples in which this framework was beneficial in pushing forward the MDGs. In Kenya, key civil society organisations started a campaign called 'Basic Needs are Basic Rights', of which a key part was Elimu Yetu, the Campaign for Basic Education as a Basic Right (see also Musyoki and Nyamu-Musembi, this issue). The Campaign worked with the media and key political actors to advocate for basic rights to be included in the framing of the new Constitution. Several years of sustained campaigning resulted in this becoming a political issue in the election campaign for all parties. Consequently, among the first policy pronouncements of the new Government in December 2003 was to make primary education free. This resulted in hundreds of thousands of children joining Government primary schools. The Kenyan Constitution, which is still in the making, like the South African one, is certain to have many of the basic needs enshrined as basic rights.

In April 2001, the 'Right to Food' Campaign in India filed a Public Interest Litigation that food grain stocks lying in Government warehouses should be made available through the public distribution system. Following a sustained civil society campaign with grassroots participation in 14 States and 
widespread media coverage of people's hearings, etc., the Supreme Court directed all State Governments in November 2001 to introduce cooked mid-day meals in primary schools within six months of the order. Since the Supreme Court order came out, the 'Right to Food' Campaign has been monitoring and campaigning for State Governments to actually fulfil their obligations. Both these campaigns very effectively used human rights frameworks as levers of moral and legal persuasion.

Women's movements are the first to have realised and used the power of converting demands into rights. The legal provisions followed the popular framing of the issues in a rights discourse. This happened in the case of child rights and is beginning to take shape in the case of people living with HIV/AIDS. And the process is essentially of identifying and monitoring the duty bearers and empowering the claim holders; none of which would have been possible if a minimum level of civil and political rights were not available.

A rights-based approach in both these cases led to important gains in implementing access to housing and food security. And as women's movements have shown, shifting the discourse from service-delivery and clients, to that of rights-based claims and citizens, is key to challenging underlying structural power relations and the causes of marginalisation. The relationship between a rightsbased approach and MDGs is interdependent and mutually reinforcing. But for this, advocates of human rights and development actors, who have traditionally worked in parallel lines, will have to come together to work much more closely, drawing

\section{Notes}

* This article is adapted from a speech given to the New York University School of Law in November 2003, entitled 'Human rights perspectives on the MDGs'.

1. The Millennium Development Goals were agreed by world leaders at the Millennium Summit in September 2000. Each goal has specific targets to be achieved by 2015, using 1990 as a benchmark. The eight goals are: (1) to eradicate extreme poverty and hunger, (2) to achieve universal primary education, (3) to promote gender equality and empower women, (4) to reduce child mortality, (5) to improve maternal health, (6) to combat on each other's power and language. This is starting to happen: Oxfam GB and Amnesty International are running the first joint campaign on small arms. As national MDG reports get published, there is significant scope to act as alternative reports to the official Economic, Social and Cultural Rights (ESCR) country reports. MDG indicators could be reframed in the national context. For example, the impact of women's access to credit could be looked at in terms of increased incomes as well as in terms of their participation in the political process and the elimination of domestic violence. The rights-based framework could influence budgeting and resource allocation processes for MDGs. The Millennium Campaign can work to support links between rights and the MDGs. At the national level, there is also increasing scope for legal provisioning. Many developed countries are starting to have laws for international cooperation and international institutions are legally accountable to their member governments. Various UN agencies have already been advocated rights through their work.

As rights come under threat in many parts of the world, the strong link between rights and the MDGs is increasingly important. This article has outlined how the two are linked and mutually reinforcing. What is needed next, is further work to identify specific steps on how we can maximise the synergy and power of human rights and MDGs working together for a world without poverty and injustice. This link is not a preference, but an absolute necessity, particularly as the human rights space in the recent period in many parts of the world has been narrowing.

HIV/AIDS, malaria and other diseases, (7) to ensure environmental sustainability, and (8) to develop a global partnership for development. For details on MDG targets, indicators and progress, see: www.undp.org/mdg

2. The MDGs, at least in my current understanding, are not legally enforceable at the international level and in most countries, at the national level. This is in fact the raison d'etre of the Millennium Campaign: to create the necessary conditions for creative political and moral pressure, where no explicit legal provisions might exist to enforce the MDGs. The inspiration for this approach comes from several recent examples at the national and international levels. 